University of Nebraska - Lincoln

DigitalCommons@University of Nebraska - Lincoln

Biological Systems Engineering: Papers and Publications

Biological Systems Engineering

7-16-2006

\title{
Yield Response of Corn to Deficit Irrigation in a Semiarid Climate
}

José O. Payero

University of Nebraska-Lincoln, jpayero@clemson.edu

Steven R. Melvin

University of Nebraska-Lincoln, smelvin1@unl.edu

Suat Irmak

University of Nebraska-Lincoln, suat.irmak@unl.edu

David D. Tarkalson

University of Nebraska-Lincoln, david.tarkalson@ars.usda.gov

Follow this and additional works at: https://digitalcommons.unl.edu/biosysengfacpub

Part of the Biological Engineering Commons

Payero, José O.; Melvin, Steven R.; Irmak, Suat; and Tarkalson, David D., "Yield Response of Corn to Deficit Irrigation in a Semiarid Climate" (2006). Biological Systems Engineering: Papers and Publications. 52. https://digitalcommons.unl.edu/biosysengfacpub/52

This Article is brought to you for free and open access by the Biological Systems Engineering at DigitalCommons@University of Nebraska - Lincoln. It has been accepted for inclusion in Biological Systems Engineering: Papers and Publications by an authorized administrator of DigitalCommons@University of Nebraska Lincoln. 
Published in Agricultural Water Management 84:1-2 (July 16, 2006), pp. 101-112; doi: 10.1016/j.agwat.2006.01.009

Copyright $\odot 2006$ Elsevier B.V. Used by permission. http://www.elsevier.com/locate/agwat

A contribution of the University of Nebraska Agricultural Research Division, Lincoln, NE 68583. Journal Series No. 14687.

Accepted January 23, 2006; published online March 9, 2006.

\title{
Yield response of corn to deficit irrigation in a semiarid climate
}

\author{
José O. Payero, ${ }^{\text {a }}$ Steven R. Melvin, ${ }^{\mathrm{b}}$ Suat Irmak, ${ }^{\mathrm{c}}$ and David Tarkalson ${ }^{\mathrm{a}}$ \\ a University of Nebraska-Lincoln, West Central Research and Extension Center, \\ 461 West University Drive, North Platte, NE 69101, USA \\ ${ }^{b}$ University of Nebraska-Lincoln Cooperative Extension, Curtis, NE, USA \\ c Department of Biological Systems Engineering, University of Nebraska-Lincoln, \\ 234 L.W. Chase Hall, Lincoln, NE 68583-0726, USA \\ Corresponding author - J. O. Payero, tel 308 696-6707, fax 308 532-3823, email jpayero2@unl.edu
}

\begin{abstract}
Irrigation water supplies are decreasing in many areas of the U.S. Great Plains, which is requiring many farmers to consider deficit-irrigating corn (Zea mays L.) or growing crops like winter wheat (Triticum aestivum L.) that require less water, but that are less profitable. The objectives of this study were to: (1) quantify the yield response of corn to deficit irrigation, and (2) determine which of several seasonal water variables correlated best to corn yield in a semiarid climate. Eight (T1T8) and nine (T1-T9) deficit-irrigated treatments (including dryland), were compared in 2003 and 2004 in North Platte, Nebraska. The actual seasonal crop evapotranspiration $\left(\mathrm{ET}_{\mathrm{d}}\right)$ (calculated with procedures in FAO-56) for the different treatments was 37-79\% in 2003 and 63-91\% in 2004 compared with the seasonal crop evapotranspiration when water is not limited $\left(\mathrm{ET}_{\mathrm{w}}\right)$. Quantitative relationships between grain yield and several seasonal water variables were developed. Water variables included, irrigation $(I)$, total water $\left(W_{\text {all }}\right)$, rain + irrigation $\left(W_{R+I}\right)$, evaporation $(E)$, crop evapotranspiration $\left(E T_{d}\right)$, crop transpiration $\left(T_{d}\right)$, and the ratios of $E T_{d}$ and $T_{d}$ to evapotranspiration and transpiration when water is not limited $\left(\mathrm{ET}_{\mathrm{w}}\right.$ and $\mathrm{T}_{\mathrm{w}}$ ). Both years, yield increased linearly with seasonal irrigation, but the relationship varied from year to year. Combining data from both years, $\mathrm{ET}_{\mathrm{d}}$ had the best correlation to grain yield (yield $=0.028 \mathrm{ET}_{\mathrm{d}}-5.04, R^{2}=0.95$ ), and the water variables could be ranked from higher to lower $R^{2}$ when related to grain yield as: $\mathrm{ET}_{\mathrm{d}\left(R^{2}=0.95\right)}>T_{\mathrm{d}\left(R^{2}=0.93\right)}$ $>\mathrm{ET}_{\mathrm{d}} / \mathrm{ET}_{\mathrm{w}(R=0.90)}^{2}=T_{\mathrm{d}} / T_{\mathrm{w}(R=0.90)}^{2}>W_{\text {all }(R=0.89)}^{2}>E_{(R=0.75)}^{2}>W_{\mathrm{R}+\mathrm{I}(R=0.65)}^{2}>I_{(R=0.06)}^{2}$. Crop water productivity (CWP) (yield per unit $\left.\mathrm{ET}_{\mathrm{d}}\right)$ linearly increased with $\mathrm{ET}_{\mathrm{d}} / \mathrm{ET}_{\mathrm{w}}\left(R^{2}=0.75\right)$, which suggests that trying to increase CWP by deficit-irrigating corn is not a good strategy under the conditions of this study.
\end{abstract}

Keywords: evapotranspiration, deficit irrigation, corn, maize, crop water productivity, water variable, water use efficiency

\section{Introduction}

Irrigation water supplies are decreasing in many areas of the Great Plains of the USA. Some of the reasons for this decrease include extended drought periods, decline in groundwater levels (McGuire, 2004; McGuire and Fischer, 1999), litigation among states related to surface water allocations, and diversion of water from irrigation to environmental uses (Lingle and Franti, 1998). This situation is forcing farmers to consider the options of deficit-irrigating crops like corn or growing alternative crops like winter wheat that require less irrigation water, but that are generally less profitable. Knowing the quantitative response of crops to limited water supplies under specific environments is critical to be able to 
perform economic comparisons among local cropping options. In the US Great Plains, developing local and current information on water-yield relationships is particularly important for corn (Zea mays L.), since this crop covers more irrigated area than any other crop in the region (Norwood, 2000).

Deficit irrigation creates water stress that can affect the growth and development of corn plants. The response of corn plants to water stress has been shown to change with hybrid (Lorens et al., 1987) and can be affected by improving technological level (Dale and Daniels, 1995). Effects of water stress on corn include the visible symptoms of reduced growth, delayed maturity, and reduced crop yield. For instance, water stress has been shown to reduce corn canopy height (Denmead and Shaw, 1960; Gavloski et al., 1992; Traore et al., 2000), leaf area index (NeSmith and Ritchie, 1992; Traore et al., 2000), and root growth (Gavloski et al., 1992; Jama and Ottman, 1993). Jama and Ottman (1993) found that stressing corn during the vegetative stage in an arid environment hindered root development, which restricted deep water uptake. However, in a wetter environment in eastern Nebraska, Newell and Wilhelm (1987) found that although a fully irrigated corn treatment had greater total profile $(0-1.5 \mathrm{~m})$ and surface $(0-0.15 \mathrm{~m})$ root length at the reproductive stage, dryland and a deficit-irrigated treatments had relatively greater root length proliferation deep in the soil profile.

The effect of water stress on reducing corn grain and biomass yields has also been studied (Denmead and Shaw, 1960; Traore et al., 2000). Grain yield can be reduced by decreasing yield components like ear size, number of kernel per ear, or the kernel weight. Claassen and Shaw (1970) observed that stress before or during silking and pollination resulted in reduced kernel number, while stress during or after silking reduced kernel weight. NeSmith and Ritchie (1992) attributed yield loss from water stress during pre-anthesis to a reduction in the number of well-developed kernels. Bryant et al. (1992) indicated that water stress reduces yield by reducing accumulated biomass and the harvest index (ratio of grain yield to aboveground plant dry weight). Traore et al. (2000), however, found that the harvest index was affected by water deficit only when stress was imposed during anthesis.

Many researchers have evaluated the effect of stress timing on corn yield (Robins and Domingo, 1953; Denmead and Shaw, 1960; Barnes and Woolley, 1969; Downey, 1971; Claassen and Shaw, 1970; Jurgens et al., 1978; NeSmith and Ritchie, 1992; Bryant et al., 1992; Jama and Ottman, 1993). Others have developed models to quantify the effect of stress timing on yield (Jensen, 1968; Nairizi and Rydzewski, 1977; Doorenbos et al., 1979; Doorenbos and Kassam, 1979; Meyer et al., 1993a, 1993b). For instance, Doorenbos et al. (1979) proposed that the effect of water stress on yield could be quantified by a linear function where the slope of the line $(\mathrm{ky})$ was an empirical yield response factor that varied depending on the growth stage when water stress occurred. For corn, they reported ky values of $0.4,1.5,0.5$, and 0.2 for the vegetative, flowering, yield formation, and ripening stages, indicating that yield was more affected by water stress during the flowering stage than at any other stage. This model suggests that if water is limited, the irrigator should time irrigation to coincide with the most sensitive stage.
Despite the body of evidence indicating that stress timing has an effect on corn yield, there is also indication that corn yield is just a linear function of seasonal evapotranspiration (ET) or transpiration (T), with no regard for stress timing. For instance, good linear relationship between corn yield and seasonal ET have been reported by Robins and Domingo (1953), Hanks (1974), Hanks et al. (1976), Gilley et al. (1980), Schneekloth et al. (1991), Barrett and Skogerboe (1978), Stone (2003), and Klocke et al. (2004). The data reported by Benoit et al. (1965) also follow a linear yield-ET function with $R^{2} \geq 0.79$. Barrett and Skogerboe (1978) pointed out that the scatter in the published crop yield versus water use data largely resulted from the time of occurrence of water deficits in relation to the stage of growth. However, they also stated that if these yields are plotted versus seasonal ET rather than the quantity of water applied, the data would likely fall on a straight line. The objectives of this study were to: (1) quantify the grain yield response of corn to deficit irrigation and (2) determine which of several seasonal water variables correlated best to corn grain yield under deficit irrigation conditions in the semiarid climate of West-Central Nebraska.

\section{Materials and methods}

\subsection{Site description}

Field data for this study were collected in 2003 and 2004 at the University of Nebraska-Lincoln West Central Research and Extension Center, North Platte, Nebraska $\left(41.1^{\circ} \mathrm{N}\right.$, $100.8^{\circ} \mathrm{W}, 861 \mathrm{~m}$ above sea level). The soil at North Platte is a Cozad silt loam (Fluventic Haplustolls) with field capacity of $0.29 \mathrm{~m}^{3} \mathrm{~m}^{-3}$ and permanent wilting point of $0.11 \mathrm{~m}^{3} \mathrm{~m}^{-3}$ (Klocke et al., 1999). The corn hybrid DeKalb C57-40 RR was planted at 0.76-m row spacing in 2003 and Renze 9363 Bt RR was planted in 2004. These hybrids had comparative relative maturities that are commonly planted in the area and were chosen for being the top yielding hybrids in local variety trials during the previous year. In 2003 corn was planted on May 13, and harvested on October 13. In 2004, corn was planted on May 10 and harvested on November 15.

The experimental plots were located within a relatively large irrigated area. Plots were irrigated using a solid-set sprinkler system, which was arranged in a grid with a sprinkler head installed on a 3.35-m riser at each corner of each plot. Each experimental plot was $12.2 \mathrm{~m} \times 12.2 \mathrm{~m}\left(148.8 \mathrm{~m}^{2}\right)$ in size, which accommodated 16 corn rows. The center four rows of each plot were harvested using a plot combine. Experimental plots were separated from each other by $12.2-\mathrm{m}$ wide border strips that were also planted to corn.

Water for the system was pumped from the Ogallala aquifer, using an electric turbine pump with a capacity of $600 \mathrm{GPM}$ at $483 \mathrm{kPa}$ of pressure. The mainline at the pumping station was instrumented with two pressure gauges, two flow meters, a pressure relief valve, a chemigation check valve, and "high" and "low" pressure switches. The flow meters measured both the instantaneous flow rate and the cumulative volume of water pumped. The irrigation system had an automatic control panel hard-wired to electric valves installed at each plot. Each electric valve controlled the four sprinklers of each plot. The control panel was also connected 
Table 1. Average of daily values of maximum air temperature $\left(T_{\max }\right)$, minimum air temperature $\left(T_{\min }\right)$, average air temperature $\left(T_{\mathrm{a}}\right)$, solar radiation $\left(R_{\mathrm{s}}\right)$, relative humidity $(\mathrm{RH})$, wind speed at 2-m height $\left(u_{2}\right)$, and grass reference evapotranspiration $\left(\mathrm{ET}_{\mathrm{o}}\right)$ for the month of May-October at North Platte, NE during 2003 and 2004

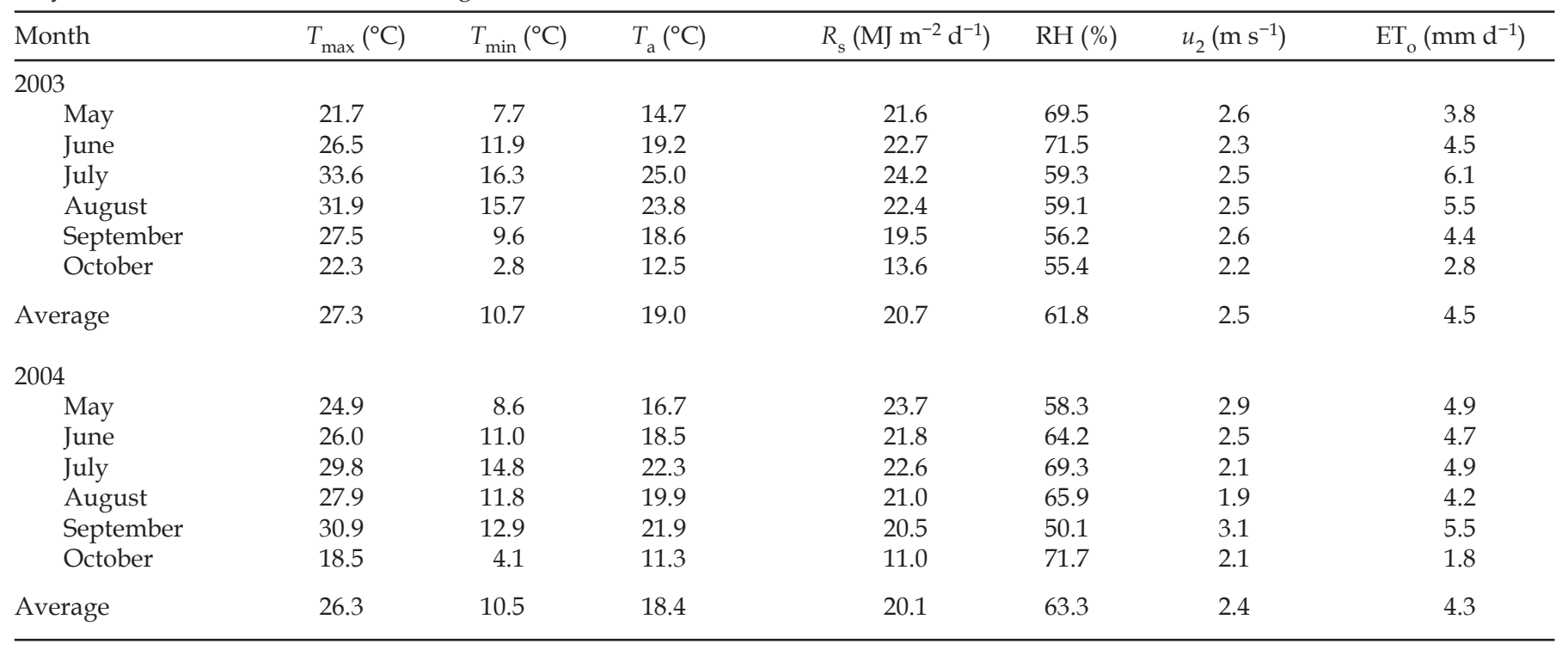

to a manual relay panel, which allowed both manual and automatic operation of the irrigation system. This design allowed irrigating each individual plot independently, and changing the randomizing of the plots from year to year to accommodate different experimental designs.

The average weather conditions at North Platte during the study are shown in Table 1 . In general, weather conditions were cooler and wetter during the 2004 growing season than in 2003. Although the average air temperature during June-October was only $0.6^{\circ} \mathrm{C}$ cooler in 2004, it was approximately $2.2^{\circ} \mathrm{C}$ cooler during the months of June, July, and August. These cooler weather conditions during 2004 delayed crop maturity and harvest about a month compared with 2003. Warmer conditions, however, prevailed in 2004 compared with 2003 during the months of May and September. Although weather conditions were cooler in 2004, the average of the daily grass-reference evapotranspiration $\left(\mathrm{ET}_{\mathrm{o}}\right)$ values for the entire May-October period was only $0.02 \mathrm{~mm} \mathrm{~d}^{-1}$ lower during 2004 (Table 1). In 2004, the average daily ET values were lower than 2003 during the months of July, August, and October, and higher during May, June, and September. Average daily ET, values in 2004 were particularly lower than 2003 during the months of July and August, which are usually the months with the peak $\mathrm{ET}_{\mathrm{o}}$ values for the North Platte area.

Rainfall was significantly less in 2003 than 2004 (Figure 1). A total of 22 rainfall events occurred during the 2003 growing season, which totaled $138 \mathrm{~mm}$ of water. In 2003, the total in-season rainfall was only enough to supply approximately $19.4 \%$ of seasonal crop water requirements $\left(\mathrm{ET}_{\mathrm{w}}\right)$. In 2004, however, there were 39 rainfall events, almost twice as many as in 2003. Rainfall in 2004 totaled $414 \mathrm{~mm}$, which supplied more than half $(54.5 \%)$ of the seasonal crop water requirements.

\subsection{Irrigation treatments}

The experiment was conducted using a randomized complete block design with four replications. Eight irrigation treatments (T1-T8) were applied in 2003 and the number of treatments was increased to nine (T1-T9) in 2004. Each year, treatments included a dryland treatment (treatment T8 in 2003 and T9 in 2004) (Table 2), which received no irrigation. This many treatments were included to obtain enough data points and a wide enough range of water stress levels to be able to develop meaningful quantitative relationships between grain yield and several seasonal water variables, including irrigation, total water, rain + irrigation, evaporation, evapotranspiration, and transpiration, among others.

Irrigation to the different treatments was scheduled trying to create differences in soil water depletions of approximately $10 \mathrm{~mm}$ between irrigated treatments, within the range of 150-250 mm. This range of soil water depletion represents between 50 and $85 \%$ of total available water in the maximum crop rooting depth. No irrigation was applied during the vegetative growth stage, following a common practice in the area, and to make sure that there would be some seasonal crop stress despite potential rainfall occurring later in the

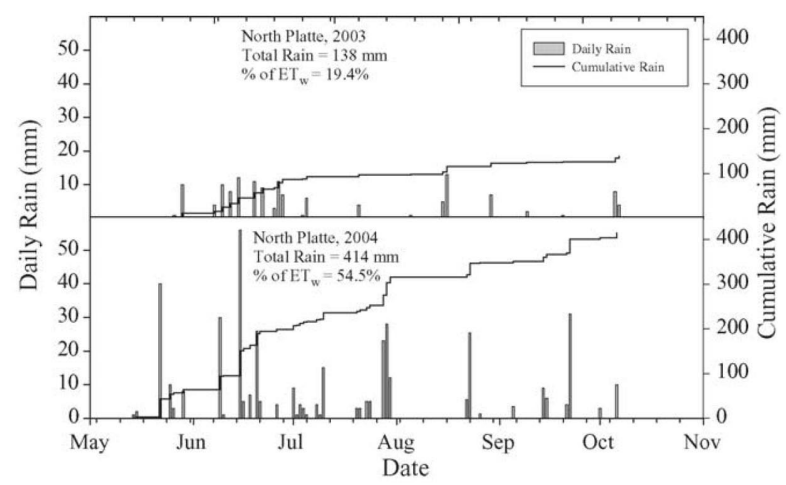

Figure 1. Daily and cumulative rain during the 2003 and 2004 corn growing seasons at North Platte. \% of $\mathrm{ET}_{\mathrm{w}}$ is the percent of seasonal crop evapotranspiration when soil water is not limiting that was supplied by in-season rainfall. 
Table 2. Irrigation (mm) applied to corn at North Platte during 2003 and 2004 for each irrigation treatment (T1-T9).

\begin{tabular}{|c|c|c|c|c|c|c|c|c|c|}
\hline Date & $\mathrm{T} 1$ & $\mathrm{~T} 2$ & $\mathrm{~T} 3$ & $\mathrm{~T} 4$ & T5 & T6 & $\mathrm{T} 7$ & $\mathrm{~T} 8$ & T9 \\
\hline \multicolumn{10}{|l|}{2003} \\
\hline $7 / 10 / 03$ & 34.8 & -- & & - & - & - & - & Dryland & Not included \\
\hline $7 / 11 / 03$ & 16.8 & 36.1 & 36.1 & 36.1 & - & - & - & - & - \\
\hline $7 / 18 / 03$ & 20.8 & 27.7 & 27.7 & 27.7 & 84.1 & 84.1 & 84.1 & - & - \\
\hline $7 / 22 / 03$ & 33.5 & 35.6 & 35.6 & 35.6 & - & - & - & - & - \\
\hline $7 / 26 / 03$ & 13.0 & 23.6 & 23.6 & 23.6 & - & - & - & - & - \\
\hline $7 / 31 / 03$ & - & - & - & 36.8 & - & 15.2 & - & - & - \\
\hline $8 / 8 / 03$ & 33.5 & - & - & - & - & - & - & - & - \\
\hline $8 / 9 / 03$ & - & - & 46.7 & 46.7 & 46.7 & - & 46.7 & - & - \\
\hline $8 / 11 / 03$ & 25.4 & 6.4 & 6.4 & 6.4 & 6.4 & - & - & - & - \\
\hline $8 / 13 / 03$ & - & 16.5 & - & - & - & - & - & - & - \\
\hline $8 / 18 / 03$ & 35.1 & 70.1 & - & - & - & - & - & - & - \\
\hline $8 / 19 / 03$ & 28.7 & - & 47.5 & 18.8 & 18.8 & 18.8 & - & - & - \\
\hline $9 / 3 / 03$ & - & 6.6 & - & - & - & - & - & - & - \\
\hline $9 / 9 / 03$ & 30.2 & 20.1 & 30.2 & 30.2 & 20.1 & 20.1 & 20.1 & - & - \\
\hline Total & 394.7 & 336.3 & 304.5 & 331.2 & 269.7 & 196.1 & 244.6 & 0.0 & - \\
\hline$\%$ of $\mathrm{ET}_{\mathrm{w}}{ }^{\mathrm{a}}$ & 55.7 & 47.3 & 43.7 & 47.4 & 38.2 & 31.4 & 34.7 & 0.0 & - \\
\hline \multicolumn{10}{|l|}{2004} \\
\hline 8/9/04 & 11.7 & - & - & - & - & - & - & - & Dryland \\
\hline $8 / 11 / 04$ & 39.1 & - & - & - & - & - & - & - & - \\
\hline $8 / 12 / 04$ & - & 10.4 & 10.4 & 10.4 & - & - & - & - & - \\
\hline $8 / 13 / 04$ & - & - & - & 22.6 & 22.6 & 22.6 & 22.6 & - & - \\
\hline $8 / 17 / 04$ & 35.8 & - & - & - & - & - & - & - & - \\
\hline $8 / 19 / 04$ & - & - & - & - & - & 11.4 & 11.4 & 11.4 & - \\
\hline
\end{tabular}

${ }^{\mathrm{a}} \%$ of $\mathrm{ET}_{\mathrm{w}}$ is the percent of seasonal crop evapotranspiration when soil water is not limiting that was supplied by irrigation.

growing season. Depths and timings of irrigation events applied to each irrigation treatment during the 2003 and 2004 growing seasons are shown in Table 2. Due to more in-season rainfall, seasonal irrigation amounts and the number of irrigation events per treatment were significantly less in 2004 than 2003. In 2003, seasonal irrigation depths per treatment ranged from approximately 245 to $395 \mathrm{~mm}$. These seasonal irrigation depths supplied between 34.7 and $55.7 \%$ of seasonal crop water requirements $\left(\mathrm{ET}_{\mathrm{w}}\right)$. In 2004, seasonal irrigation depths ranged from 34 to $161 \mathrm{~mm}$, representing between 4.7 and $21.2 \%$ of seasonal $\mathrm{ET}_{\mathrm{w}}$. In 2003, the first irrigation to some of the irrigated treatments was applied in early July. In 2004, rainfall early in the season allowed delaying the first irrigation to any of the treatments until early August. The last irrigation during both years was applied in early September.

Irrigation scheduling at both sites was done using a scheduling spreadsheet that used the calculated daily corn evapotranspiration as input to estimate daily soil water content in the crop root zone. When actual soil water measurements were available, they were used to adjust the spreadsheet estimates. Soil water measurements were made approximately every 2 weeks during the growing season using the neutron scattering method. Soil water readings were taken from $50-\mathrm{mm}$ diameter aluminum access tubes installed at the center of two of the four replications for each treatment. Readings were taken at $0.3-\mathrm{m}$ depth increments to a depth of $1.8 \mathrm{~m}$. Weather data for this study were obtained from an automatic weather station located within $1.5 \mathrm{~km}$ from the research site. This weather station was part of the High Plains Regional Climate Center (HPRCC) weather network. Daily weather data were downloaded from the HPRCC web site (http://www.hprcc.unl.edu/home.html), including daily maximum and minimum air temperature, relative humidity, wind speed, rainfall, solar radiation, reference ET, and crop ET for different crops, including corn.

\subsection{Data analyses}

The statistical analyses of yield data, which included analysis of variance (ANOVA) and separation of means by 
the Duncan's new multiple range test, were conducted using the SAS ${ }^{\circledR}$ System for Windows statistical software (SAS Institute, Inc., Cary, NC). A computer program was written in Microsoft Visual Basic to model the daily soil water status. Basic input to the program included daily weather data, rainfall, irrigation, the soil water profile at crop emergence, and crop-specific and site-specific information such as planting date, maturity date, soil parameters, maximum rooting depth, etc. Based on these inputs, the water balance in the crop root zone was calculated on a daily basis. Similar soil water balance models have previously been used by Robinson and Hubbard (1990), Swan et al. (1990), and Bryant et al. (1992) to estimate daily water status and yield for corn.

The computer program calculated evapotranspiration using the procedure presented in FAO-56 (Allen et al., 1998). Since this is a lengthy procedure, readers are referred to the original source for details. According to this procedure, crop evapotranspiration can be obtained as the product of the evapotranspiration of a reference crop $\left(\mathrm{ET}_{\mathrm{o}}\right)$ and a crop coefficient $\left(K_{\mathrm{c}}\right)$. $\mathrm{ET}_{\mathrm{o}}$ is calculated using the daily weather data as input to the Penman-Monteith equation, and the $K_{c}$ is used to adjust the estimated $\mathrm{ET}_{\mathrm{o}}$ for the reference crop to that of other crops at different growth stages and growing environments. $\mathrm{ET}_{\mathrm{o}}$ is the evapotranspiration of a hypothetical reference crop with an assumed crop height of $0.12 \mathrm{~m}$, a fixed surface resistance of $70 \mathrm{~s} \mathrm{~m}^{-1}$ and an albedo of 0.23 . The reference surface closely resembles an extensive surface of green grass of uniform height, actively growing, completely shading the ground and with adequate water (Allen et al., 1998). The dual crop coefficient approach was used to separate the two components of evapotranspiration, namely evapotation $(E)$ and transpiration (T) (Wright, 1982). For corn, this procedure linearly reduced crop evapotranspiration when the root zone depletion exceeded 55\% (taken from Table 22 in FAO-56) of total available water, which was used to quantify the effect of water stress on corn water use. The dual crop coefficient procedure also accounts for the sharp increases in evaporation due to a wet soil surface following rain or irrigation.

This procedure permitted calculation of the crop evapotranspiration and transpiration when soil water is not limiting $\left(\mathrm{ET}_{\mathrm{w}}\right.$ and $\left.\mathrm{T}_{\mathrm{w}}\right)$, and the actual crop evapotranspiration, transpiration, and evaporation $\left(\mathrm{ET}_{\mathrm{d}}, T_{\mathrm{d}}\right.$, and $\left.E\right)$. From the seasonal values, the seasonal $\mathrm{ET}_{\mathrm{d}} / \mathrm{ET}_{\mathrm{w}}$ and $T_{\mathrm{d}} / T_{\mathrm{w}}$ ratios were calculated for each treatment. It was expected that the seasonal $\mathrm{ET}_{\mathrm{d}} / \mathrm{ET}_{\mathrm{w}}$ and $T_{\mathrm{d}} / T_{\mathrm{w}}$ ratios would relate to crop yield. Additionally, in FAO-56, an equation was presented to estimate the fraction of total available soil water in the root zone $(p)$ that can be depleted from the root zone before moisture stress (reduction in $\mathrm{ET}_{\mathrm{d}}$ ) occurs. This equation estimates a variable $p\left(p_{\text {calc }}\right)$ as a function of daily $\mathrm{ET}_{\mathrm{w}}$ as:

$$
p_{\text {calc }}=p_{\text {table }}+0.04\left(5-\mathrm{ET}_{\mathrm{w}}\right)
$$

where, $p_{\text {table }}$ is the $p$ value taken from Table 22 in FAO-56, and $\mathrm{ET}_{\mathrm{w}}$ is in $\mathrm{mm} \mathrm{day}^{-1}$ and $0.1 \leq p_{\text {calc }} \leq 0.8$. This equation suggests that as $\mathrm{ET}_{\mathrm{w}}$ for a given day decreases, it is easier for the crop to sustain $\mathrm{ET}_{\mathrm{w}}$ rates, and therefore, higher soil water depletion levels could be allowed without yield loss, as previously proposed by Doorenbos et al. (1979). This way of calculating a variable $p$ value differs from the common pro- cedure of using a fixed $p$ value for a given crop for the entire growing season. In this study, the daily $p_{\text {calc }}$ values were calculated, which were taken as the theoretical optimum depletion value for a given day. Also, a daily actual $p\left(p_{\text {actual }}\right)$ was calculated as:

$$
\begin{aligned}
& p_{\text {actual }}=D / \text { TAW } \\
& \text { TAW }=1000\left(\theta_{\mathrm{FC}}-\theta_{\mathrm{PWP}}\right) Z_{\mathrm{r}}
\end{aligned}
$$

where $D$ is the soil water depletion in the crop root zone $(\mathrm{mm}), \theta_{\mathrm{FC}}$ the soil water content at field capacity $\left(\mathrm{m}^{3} \mathrm{~m}^{-3}\right)$, $\theta_{\mathrm{PWP}}$ the soil water content at permanent wilting point $\left(\mathrm{m}^{3} \mathrm{~m}^{-3}\right), Z_{\mathrm{r}}$ the crop rooting depth $(\mathrm{m})$, and TAW is the total available soil water in the crop root zone $(\mathrm{mm})$. A maximum rooting depth of $1.7 \mathrm{~m}$ was assumed for corn (taken from Table 22 in FAO-56). In this study, it was expected that $p_{\text {dif }}$ $\mathrm{f}=\left(p_{\text {actual }}-p_{\text {calc }}\right)$ accumulated for the entire season only for days when $p_{\text {diff }}>0$ (seasonal $p_{\text {diff }}$ ) would be a good indicator of the level of crop stress and would, therefore, relate to crop yield. The greater the seasonal $p_{\text {diff }}$ for a given treatment the greater the level of water stress. Seasonal $p_{\text {diff }}$ was therefore calculated for each treatment.

The effect of irrigation treatments on crop yield was also evaluated by calculating the crop water productivity (CWP) (Zwart and Bastiaanssen, 2004) as:

$$
\mathrm{CWP}=\left[\mathrm{Y}_{\mathrm{a}} /\left(\text { seasonal } \mathrm{ET}_{\mathrm{d}}\right)\right] / 10
$$

where $Y_{\mathrm{a}}$ is the crop yield $\left(\mathrm{kg} \mathrm{ha}^{-1}\right)$, seasonal $\mathrm{ET}_{\mathrm{d}}$ the seasonal actual crop evapotranspiration ( $\mathrm{mm}$ ), and CWP is in $\mathrm{kg} \mathrm{m}^{-3}$. Since 1 ha-mm $=10 \mathrm{~m}^{3}, 10$ is needed to convert CWP from units of $\mathrm{kg} \mathrm{ha}^{-1} \mathrm{~mm}^{-1}$ to $\mathrm{kg} \mathrm{m}^{-3}$. The CWP is sometimes

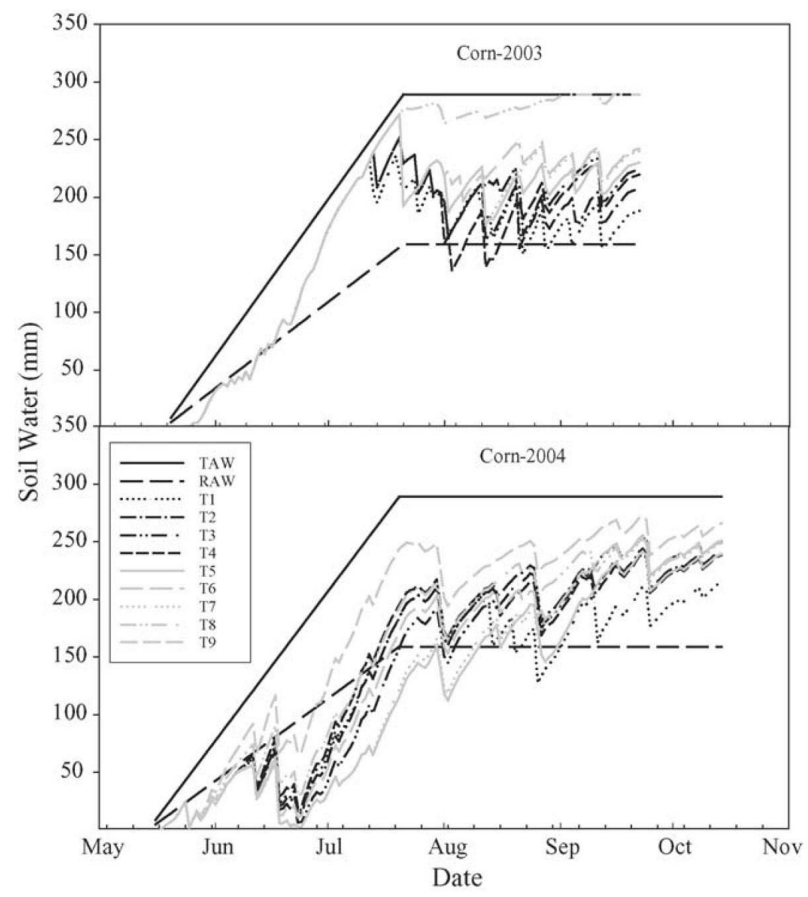

Figure 2. Daily soil water depletion in the crop root zone for the different irrigation treatments (T1-T9) at North Platte during the 2003 and 2004 growing seasons. TAW is the total available water in the crop root zone and RAW is the readily available water (RAW $=0.55 T A W)$. 


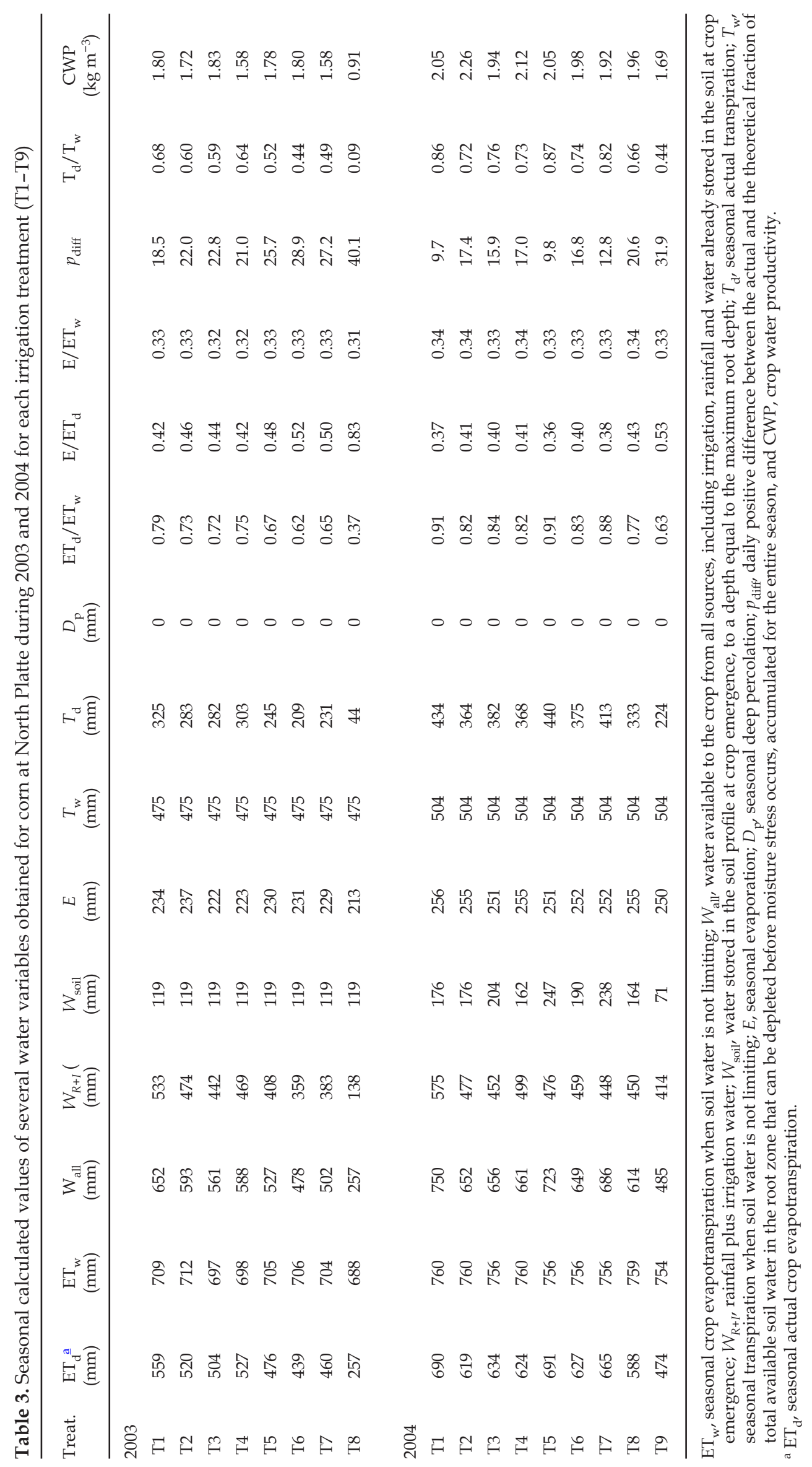


equivalent to water use efficiency (WUE) as defined by Howell (2000), although sometimes researchers define WUE in terms of seasonal irrigation applied instead of seasonal $\mathrm{ET}_{\mathrm{d}}$. This study also evaluated the relationships between several other water variables and corn grain yield. These variables included seasonal $\mathrm{ET}_{\mathrm{d}}, T_{\mathrm{d}}, E$, irrigation applied $(I)$, rain + irrigation $\left(W_{R+I}\right)$, and total water available to crop during the growing season $\left(W_{\text {all }}\right)$. Grain yields were also normalized by calculating the $\%$ yield potential $\left(\% Y_{p}\right)$ and the $\%$ maximum yield $\left(\% Y_{\max }\right)$. The maximum yield obtained within each season was taken as a reference to calculate $\% Y_{\max }$. The potential yield for each season was estimated using the HybridMaize simulation model developed by Yang et al. (2004).

\section{Results and discussion}

\subsection{Yield response to water deficit}

Irrigation treatments resulted in differences in daily soil water depletions in the crop root zone as shown in Figure 2. To avoid water stress, best management practices commonly recommend maintaining root zone depletion below the readily available water (RAW) line (Figure 2). Figure 2, however, shows that in 2003, delaying irrigation until early July resulted in water stress for all treatments occurring after mid June. Limited water inputs after that time also resulted in water stress levels for the different treatments that ranged from mild to severe. In 2004, except for the dryland treatment, stress to most treatments only occurred after mid July. Limited water inputs in 2004 also resulted in some level of stress for all treatments, especially late in the growing season. In 2004, similarly to 2003, the dryland treatment suffered from water stress during most of the growing season, although the level of stress at the end of the growing season for this treatment was more severe in 2003 than 2004.

Irrigation treatments also resulted in differences in seasonal values of several water variables as shown in Table 3. Although the 2004 growing season was cooler and wetter than 2003, the seasonal values of $\mathrm{ET}_{\mathrm{w}}$ were higher in 2004 due to the longer growing season, resulting from delayed crop maturity, and to increased soil evaporation due to more frequent wetting of the soil surface by rainfall. Values of seasonal $\mathrm{ET}_{\mathrm{d}}$ for the different treatments were also higher in 2004 since there was more water available to the crop compared with 2003. The seasonal values of $\mathrm{ET}_{\mathrm{d}} / \mathrm{ET}_{\mathrm{w}}$ per treatment ranged from 0.37 to 0.79 in 2003 and from 0.63 to 0.91 in 2004. The values of the $\mathrm{ET}_{\mathrm{d}} / \mathrm{ET}_{\mathrm{w}}$ ratio indicate that all treatments experienced some water stress during the growing season. No deep percolation $\left(D_{\mathrm{p}}\right)$ occurred during the study for any of the irrigation treatments.

In 2004, there was slightly more seasonal evaporation $(E)$ for all treatments compared with 2003. The values for $\mathrm{E} / \mathrm{ET}_{\mathrm{w}}$ in Table 3 show that the seasonal evaporation represented about $1 / 3$ of $\mathrm{ET}_{\mathrm{w}}$ during both seasons for all treatments. This is a significant amount of water that does not directly contribute to crop yield. In this study, however, most of the evaporation resulted from rainfall instead of irrigation. Most of the $E$ also occurred early in the growing season when there was a partial canopy cover and the soil surface was exposed to direct solar energy. To achieve the objective of producing more crop yield per unit of water there is still potential for reducing the evaporation component of $\mathrm{ET}_{\mathrm{w}}$ in addition to the application of other water-saving techniques (Kijne et al., 2003).

Irrigation treatments also resulted in differences in grain yields as shown in Table 4. Higher yields were obtained in 2004 since there was more water available to the crop in all treatments compared with 2003. The analysis of variance resulted in significant yield differences during both growing seasons. However, during the 2003 season the separation of means analysis resulted in five different groups of treatments, while in 2004 only the dryland treatment (T9) had significantly lower grain yield than the other treatments. Running the Hybrid-maize simulation model of Yang et al. (2004) assuming adequate irrigation, potential yields for corn at North Platte were estimated at $13.3 \mathrm{Mg} \mathrm{ha}^{-1}$ for 2003 and $16.9 \mathrm{Mg} \mathrm{ha}^{-1}$ for 2004. These potential yields were used to calculate the $\%$ potential yield $\left(\% Y_{p}\right)$ shown in Table 4 . The maximum yield was 10.1 Mg ha ${ }^{-1}$ in 2003 and 14.2 $\mathrm{Mg} \mathrm{ha}^{-1}$ in 2004. Based on these

Table 4. Corn grain yields, $\%$ potential yield $\left(\% Y_{\mathrm{p}}\right)$, and $\%$ maximum yield $\left(\% Y_{\max }\right)$ for each irrigation treatment $(\mathrm{T} 1-\mathrm{T} 9)$ obtained at North Platte during 2003 and 2004

\begin{tabular}{|c|c|c|c|c|c|c|}
\hline Irrigation treatment & $\begin{array}{l}2003 \\
\text { Yield }\left(\mathrm{Mg} \mathrm{ha}^{-1}\right)^{\mathrm{a}}\end{array}$ & $\% Y_{\mathrm{p}}$ & $\% Y_{\max }$ & $\begin{array}{l}2004 \\
\text { Yield }\left(\mathrm{Mg} \mathrm{ha}^{-1}\right)\end{array}$ & $\% Y_{\mathrm{p}}$ & $\% Y_{\max }$ \\
\hline $\mathrm{T} 1$ & $10.1 \mathrm{a}$ & 75.9 & 100.0 & $14.2 \mathrm{a}$ & 83.8 & 100.0 \\
\hline T3 & $9.2 \mathrm{ab}$ & 69.6 & 91.7 & $12.3 \mathrm{a}$ & 72.6 & 86.7 \\
\hline $\mathrm{T} 4$ & $8.3 \mathrm{bc}$ & 62.7 & 82.6 & $13.2 \mathrm{a}$ & 78.2 & 93.4 \\
\hline T5 & $8.5 b c$ & 63.8 & 84.1 & $14.2 \mathrm{a}$ & 83.8 & 100.0 \\
\hline $\mathrm{T} 7$ & $7.3 \mathrm{c}$ & 55.0 & 72.4 & $12.8 \mathrm{a}$ & 75.6 & 90.3 \\
\hline $\mathrm{T} 8$ & $2.4 \mathrm{~d}$ & 17.7 & 23.4 & $11.5 \mathrm{a}$ & 68.2 & 81.4 \\
\hline T9 & - & - & - & $8.0 \mathrm{~b}$ & 47.4 & 56.6 \\
\hline
\end{tabular}

The $\% Y_{p}$ values are based on estimated yield potential values of $13.3 \mathrm{Mg} \mathrm{ha}^{-1}$ for 2003 and $16.9 \mathrm{Mg} \mathrm{ha}^{-1}$ for 2004 using the Hybrid-Maize simulation model (Yang et al., 2004).

a ANOVA was used to determine significance of treatment main effect for yield for each year. The Duncan New Multiple Range test was used to separate means when the treatment main effect was significant. For a given year, yields with the same letter are not significantly different. 

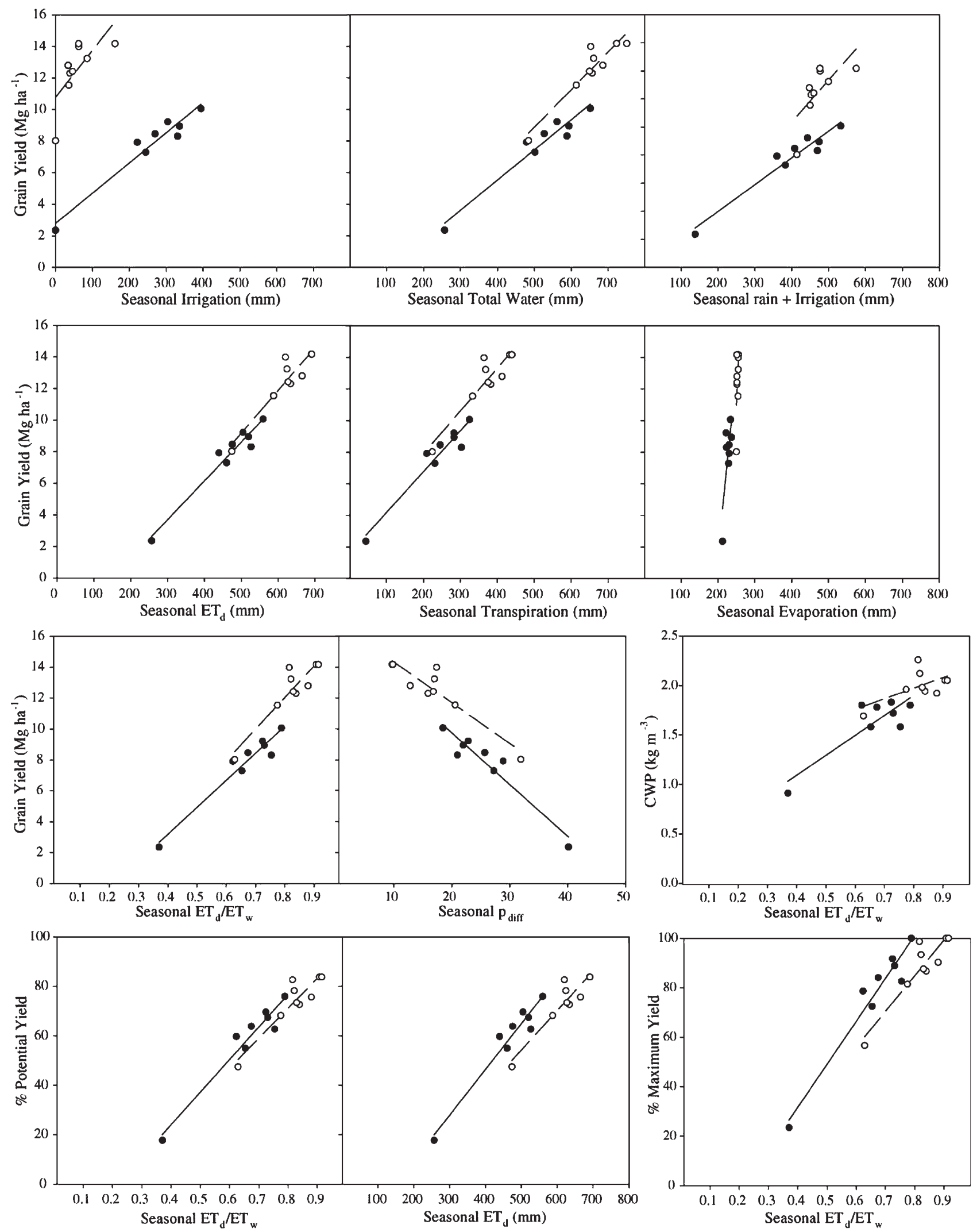

Figure 3. Relationships among different variables for corn obtained at North Platte during 2003 (solid circles) and 2004 (open circles). ET and $_{\mathrm{d}}$ are actual crop evapotranspiration and transpiration, $\mathrm{ET}_{\mathrm{w}}$ and $T_{\mathrm{w}}$ are crop evapotranspiration and transpiration when soil water is not limiting, $p_{\text {diff }}$ is daily positive difference between the actual and the theoretical fraction of total available soil water in the root zone that can be depleted before moisture stress occurs, accumulated for the entire season, and CWP is crop water productivity. The solid and dashed lines are linear regression lines. 
Table 5. Results of linear regression analysis for corn at North Platte for 2003, 2004, and combining data from both years

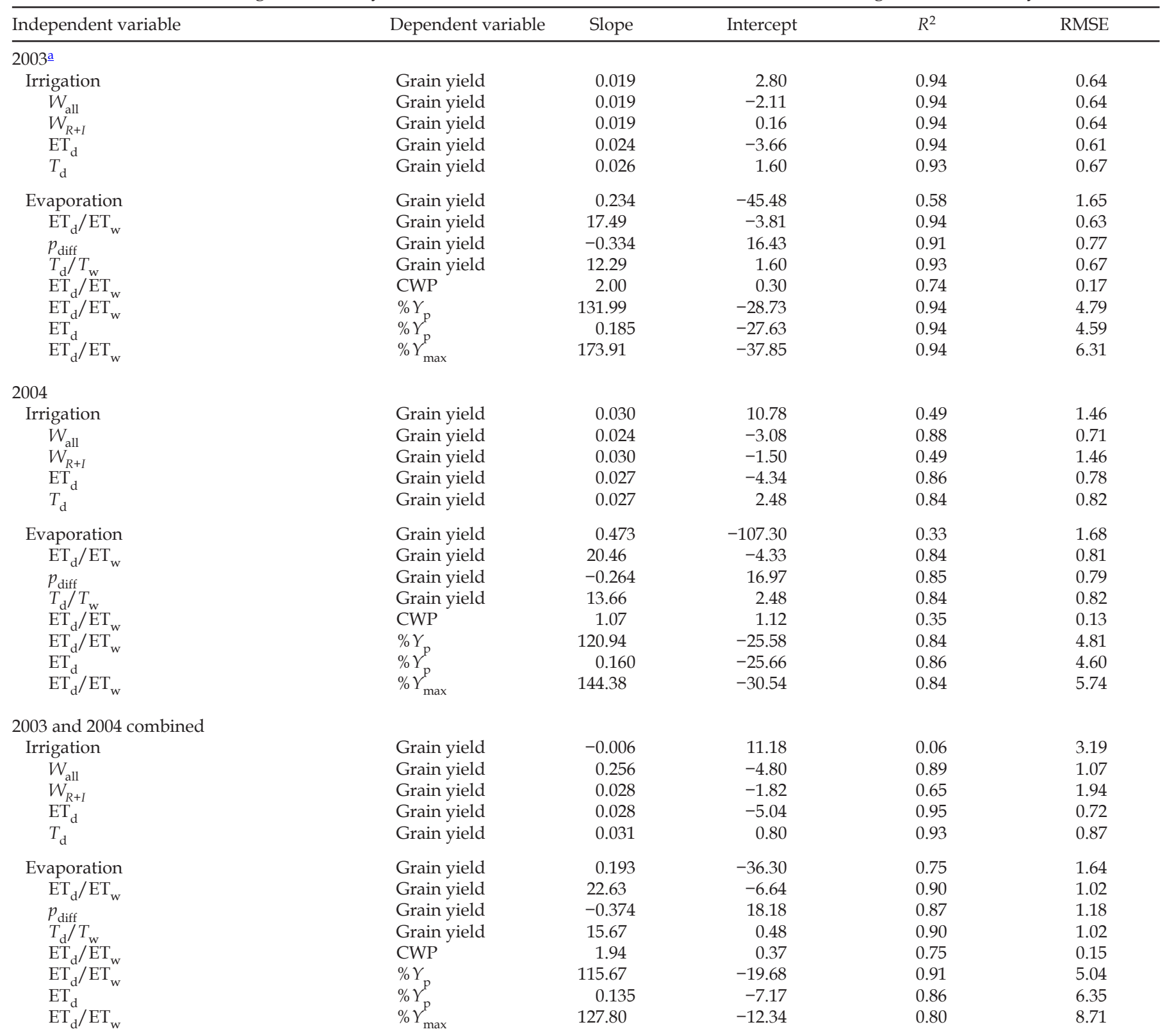

$\mathrm{ET}_{\mathrm{w}^{\prime}}$ seasonal crop evapotranspiration when soil water is not limiting; $W_{\text {all, }}$ water available to the crop from all sources, including irrigation, rainfall and water already stored in the soil at crop emergence; $W_{R+I^{\prime}}$ rain + irrigation, $T_{\mathrm{d}^{\prime}}$, seasonal actual transpiration; $T_{\mathrm{w}}$, seasonal transpiration when soil water is not limiting, $p_{\text {diff }}$ daily positive difference between the actual and the theoretical fraction of total available soil water in the root zone that can be depleted before moisture stress occurs, accumulated for the entire season; CWP, crop water productivity (kg m-3); \% $Y_{p^{\prime}} \%$ yield potential; \% $Y_{\max ^{\prime}} \%$ maximum yield for each season, grain yield is in $\mathrm{Mg} \mathrm{ha}^{-1}$, and all water variables are in units of mm. RMSE is the root mean squared error.

${ }^{\mathrm{a}} \mathrm{ET}_{\mathrm{d}}$, seasonal actual crop evapotranspiration.

maximum yields, the $\%$ maximum yield $\left(\% Y_{\max }\right)$ per treatment was also calculated (Table 4 ). The $\% Y_{p}$ for the different irrigation treatments ranged between 17.7 and $75.9 \%$ in 2003 and from 47.4 to $83.8 \%$ in 2004 . During both years, soil water deficit was the main yield-limiting factor.

\subsection{Effect of seasonal water variables on grain yield}

The relationships between yield and several seasonal water variables obtained during 2003 and 2004 are shown in Figure 3. Results of regression analyses for the different wa- ter variables are shown in Table 5, which include the results of the regression analyses for each year and also combining data for both years. Figure 3 and Table 5 indicate that in 2003 there were very good linear relationships among all the yield and water variables. The poorest relationships were between evaporation and grain yield, which resulted in $R^{2}=0.58$, and between $\mathrm{ET}_{\mathrm{d}} / \mathrm{ET}_{\mathrm{w}}$ and CWP, which resulted in $R^{2}=0.74$. All other relationships resulted in $R^{2}>0.90$. Among all variables, the ones relating best to grain yield in 2003 were irrigation, $W_{\text {all }}$, and rain + irrigation, and $\mathrm{ET}_{\mathrm{d}}$, which all resulted in a high $R^{2}$ value of 0.94 . 
For 2004, however, irrigation, rain + irrigation, and evaporation were all poorly related to grain yield. Also, $\mathrm{ET}_{\mathrm{d}} / \mathrm{ET}_{\mathrm{w}}$ was poorly related to CWP in 2004, which could be due to the small range of CWP values obtained that year. All other variables were well-correlated to grain yield during 2004, resulting in $R^{2} \geq 0.84$. The poor relationship between irrigation and grain yield during 2004 could be due to several factors. First, the small seasonal irrigation amounts applied during 2004 did not provide a large enough range of irrigation among treatments to be able to observe significant yield differences, with the only exception of the dryland treatment. Second, some of the irrigation water may have been applied too late in the season to some of the treatments to be able to make an impact on crop yield. For instance, no grain yield increase resulted from applying an additional $48 \mathrm{~mm}$ of irrigation to treatment $\mathrm{T} 1$ late in the growing season (on September 8,2004 ) compared to treatment T5, which received the last irrigation on August 25, 2004 (Table 2). Both of these treatments produced the same yield, although $\mathrm{T} 1$ received $161 \mathrm{~mm}$ of irrigation, while $\mathrm{T} 5$ only received approximately $62 \mathrm{~mm}$. The difference was that there was a higher amount of soil water left in the T1 treatment at the end of the season compared to T5 (Figure 2). Figure 2 shows that at the end of the growing season, there was still some water available in the soil profile that the crop did not have time to use because it resulted from rainfall or rain that occurred too late in the growing season to have an impact on crop yield. Norwood (2000) in a 4-year study with corn in Kansas found that considerable water remained in the soil profile after harvest. These results point out the importance of applying all irrigations early enough in the growing season so that the crop has time to use the water and convert it into grain.

Figure 3 reflects the considerable variations in the relationship between grain yield and irrigation that can occur from one season to the next, as previously reported by Norwood (2000). These variations depend on how much water is stored in the soil profile at crop emergence, and the amount and distribution of in-season rainfall. These results also point out the importance of calculating variables that relate crop yield to available soil water (i.e., CWP or water use efficiency) in terms of water variables that are more stable than seasonal irrigation. Some of these more stable water variables include seasonal $\mathrm{ET}_{\mathrm{d}^{\prime}} T_{\mathrm{d}^{\prime}} \mathrm{ET}_{\mathrm{d}} / \mathrm{ET}_{\mathrm{w}^{\prime}}, W_{\mathrm{all}}, T_{\mathrm{d}} / T_{\mathrm{w}^{\prime}}$ or $p_{\text {diff }}$.

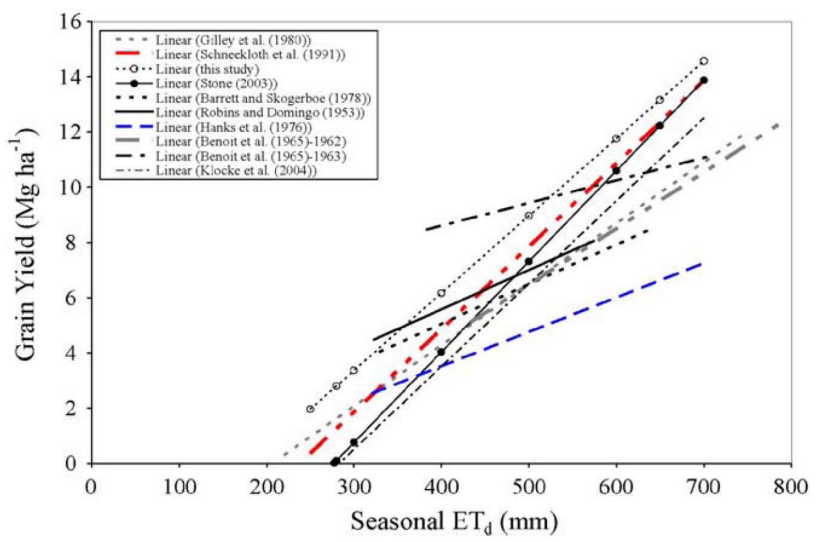

Figure 4. Linear relationships between corn grain yield and actual seasonal evapotranspiration $\left(\mathrm{ET}_{\mathrm{d}}\right)$ reported in the literature and that obtained in this study.
When data for 2003 and 2004 were combined, irrigation had the poorest relationship to grain yield $\left(R^{2}=0.06\right)$ among all variables, followed by rain + irrigation $\left(R^{2}=0.65\right)$ (Table $5)$. Even evaporation was better related to grain yield than the two previous variables $\left(R^{2}=0.75\right)$. Although evaporation itself might not contribute to crop yield directly, it is well-correlated to $\mathrm{ET}_{\mathrm{d}}\left(R^{2}=0.69\right)$, which does contribute to yield. All the remaining variables were highly correlated to grain yield. Combining both years, $\mathrm{ET}_{\mathrm{d}}$ had the best correlation to grain yield, and the water variables could be ranked from higher to lower resulting $R^{2}$ when related to grain yield as: $\mathrm{ET}_{\mathrm{d}\left(R^{2}=0.95\right)}>T_{\mathrm{d}\left(R^{2}=0.93\right)}^{2}>\mathrm{ET}_{\mathrm{d}} / \mathrm{ET}_{\mathrm{w}(R=0.90)}^{2}=T_{\mathrm{d}} / T_{\mathrm{w}(R=0.90)}^{2}$ $>W_{\text {all }(R=0.89)}^{2}>P_{\operatorname{diff}\left(R^{2}=0.87\right)}^{2}>$ evaporation $_{(R=0.75)}^{2}>$ rain + irrigation $_{(R=0.65)}>$ irrigation $_{(R=0.06)}^{2}$. The ranking of these variables, however, could change for other locations, when combining data for more than one location, or when considering an individual year or season. For instance, it was previously shown that during the dry 2003 season, irrigation, $W_{\text {all, }}$ and rain + irrigation had the highest correlation to crop yield of all the variables, while irrigation and rain + irrigation had a poor correlation to yield when data for the two seasons were combined. Normalizing grain yield as $\% Y_{\max }$ or $\% Y_{p}$ did not produce a significant improvement in the relationships between yield and the seasonal water variables compared in this study.

Figure 3 shows that in this study, it took approximately $180 \mathrm{~mm}$ of seasonal $\mathrm{ET}_{\mathrm{d}}$ for the crop to start producing grain yield. This number can be derived from the equation of the line obtained using the 2003 and 2004 data combined in Table 5 (yield $=0.028 \mathrm{ET}_{\mathrm{d}}-5.04$ ), assuming a grain yield $=0 \mathrm{Mg} \mathrm{ha}^{-1}$ (seasonal $\mathrm{ET}_{\mathrm{d}}=5.04 / 0.028=180 \mathrm{~mm}$ ). The slope of the line indicates that grain yield increased with seasonal $\mathrm{ET}_{\mathrm{d}}$ at a rate of $0.028 \mathrm{Mg} \mathrm{ha}^{-1} \mathrm{~mm}^{-1}$.

Figure 4 shows a comparison of the yield-ET ${ }_{d}$ linear relationship obtained in this study and those functions reported by other researchers. This plot seems to suggest that corn response to water could change with environment and time as new crop hybrids are developed and management practices improve. The slope of the line obtained in this study, however, is very similar to those reported by Schneekloth et al. (1991) and Klocke et al. (2004) for the same location. Schneekloth et al. (1991) reported an average yield-ET ${ }_{d}$ slope for two corn crop rotations (continuous corn and wheat-corn-soybean) during a three-year study of $0.030 \mathrm{Mg} \mathrm{ha}^{-1} \mathrm{~mm}^{-1}$. Klocke et al. (2004) also reported yield-ET ${ }_{\mathrm{d}}$ slope for corn at North Platte of $0.030 \mathrm{Mg} \mathrm{ha}^{-1} \mathrm{~mm}^{-1}$, although the intercept of the line $\left(-8.5 \mathrm{Mg} \mathrm{ha}^{-1}\right)$ was smaller than the one obtained in this study $\left(-5.04 \mathrm{Mg} \mathrm{ha}^{-1}\right)$. For the same location, Hergert et al. (1993) also reported an average marginal return for corn from the application of a deficit irrigation treatment of $150 \mathrm{~mm}$ of water of $0.027 \mathrm{Mg} \mathrm{ha}^{-1} \mathrm{~mm}^{-1}$, which was very similar to the slope of the yield-ET ${ }_{d}$ line obtained in this study. Stone (2003), however, reported a long-term yield-ET $\mathrm{d}_{\mathrm{d}}$ slope for corn in Kansas of $0.033 \mathrm{Mg} \mathrm{ha}^{-1} \mathrm{~mm}^{-1}$, which is slightly higher than the slope found in this study. This difference could be due to differences in techniques used to quantify seasonal $\mathrm{ET}_{\mathrm{d}}$ and yield, differences in climate between locations (especially the amount and distribution of in-season rainfall), differences in crop varieties and cultural practices, irrigation method, differences in irrigation scheduling practices, etc. 
The CWP increased with $\mathrm{ET}_{\mathrm{d}} / \mathrm{ET}_{\mathrm{w}}$, resulting in a $R^{2}=0.75$ when data for both years were combined (Table 5). These results suggest that trying to increase CWP by using deficit irrigation might not be a beneficial strategy under the conditions of this study as suggested by other researchers. For instance, Zwart and Bastiaanssen (2004) reviewed measured CWP for several crops around the world, including corn, and concluded that the CWP could be significantly increased if irrigation was reduced and crop water deficit was intentionally induced. Deficit irrigation would probably increase CWP only in situations where crops are being over-irrigated. The results of this study suggest that if the crop is already deficit-irrigated, lowering irrigation inputs would only contribute to further reduce yields, lowering CWP. Howell (2000) showed that WUE (calculated the same as CWP in this study) for corn increased as yield increased. It is important, however, to point out that the objective of most farmers is not to maximize CWP, but to maximize profits. Therefore, there could be very good reasons for applying deficit irrigation other than trying to maximize CWP. For example, Norwood (2000) concluded that for corn, deficit-irrigation combined with proper fertility and plant population was a viable alternative to dryland in Kansas where groundwater resources are declining. Some economic justifications for deficit irrigation strategies for corn in Nebraska have been reported by Klocke et al. (2004) and Schneekloth et al. (1995).

\section{Conclusions}

Quantitative relationships between grain yield and several seasonal water variables were developed. Seasonal water variables included, irrigation $(I)$, total water $\left(W_{\text {all }}\right)$, rain $+\mathrm{ir}-$ rigation $\left(W_{R+I}\right)$, evaporation $(E)$, actual crop evapotranspiration $\left(\mathrm{ET}_{\mathrm{d}}\right)$, actual crop transpiration $\left(T_{\mathrm{d}}\right), \mathrm{ET}_{\mathrm{d}} / \mathrm{ET}_{\mathrm{w}^{\prime}} T_{\mathrm{d}} / T_{\mathrm{w}^{\prime}}$ and $p_{\text {diff. }}$ Several of the water variables were also related to grain yield normalized as \% maximum yield and \% potential yield. A relationship between crop water productivity (CWP) and $\mathrm{ET}_{\mathrm{d}} / \mathrm{ET}_{\mathrm{w}}$ was developed. Results indicated that $E$ accounted for about $1 / 3$ of seasonal $\mathrm{ET}_{\mathrm{w}^{\prime}}$, which indicates that technologies to minimize $E$ should be developed and implemented. The linear relationship between grain yield and some of the water variables changed significantly from year to year, while others were very consistent. Combining data from both years, $\mathrm{ET}_{\mathrm{d}}$ had the best correlation to corn grain yield (yield $=0.028 \mathrm{ET}_{\mathrm{d}}-5.04, R^{2}=0.95$ ). The water variables could be ranked from higher to lower $R^{2}$ when related to grain yield as: $\mathrm{ET}_{\mathrm{d}\left(R^{2}=0.95\right)}>T_{\mathrm{d}\left(R_{2}=0.93\right)}>\mathrm{ET}_{\mathrm{d}} / \mathrm{ET}_{\mathrm{w}\left(R^{2}=0.90\right)}=T_{\mathrm{d}} /$ $T_{\mathrm{w}\left(R^{2}=0.90\right)}>W_{\text {all }(R=0.89)}{ }^{2}>P_{\operatorname{diff}\left(R^{2}=0.87\right)}>E_{(R=0.75)}{ }^{2}>W_{R+I(R=0.65)}$ $\left.>I_{(R}^{2}=0.06\right)$. The CWP linearly increased with $\mathrm{ET}_{\mathrm{d}} / \mathrm{ET}_{\mathrm{w}}$ $\left(R^{2}=0.75\right)$. These results indicate that trying to increase CWP by imposing deficit irrigation for corn might not be a beneficial strategy under the conditions of this study. However, it is recognized that there could be other good justifications for deficit irrigating corn in this environment, other than increasing CWP.

\section{References}

Allen et al., 1998 Allen, R. G., Pereira, L. S., Raes, D., Smith, M., 1998. Crop Evapotranspiration-Guidelines for Computing Crop Water Requirements. Irrigation and Drainage Paper No. 56. Food and Agriculture Organization of the United Nations (FAO), Rome, Italy.

Barnes and Woolley, 1969 D. L. Barnes and D. G. Woolley, Effect of moisture stress at different stages of growth. I. Comparison of single-eared and two-eared corn hybrids, Agron. J. 61 (1969), pp. 788-790.

Barrett and Skogerboe, 1978 J. W. H. Barrett and G. V. Skogerboe, Effect of irrigation regime on maize yields, J. Irrig. Drain. Div. 104 (1978), pp. 179-194.

Benoit et al., 1965 G. R. Benoit, A. L. Hatfield and J. L. Ragland, The growth and yield of corn. III. Soil moisture and temperature effects, Agron. J. 57 (1965), pp. 223-226.

Bryant et al., $1992 \rightarrow$ K. J. Bryant, V. W. Benson, J. R. Kiniry, J. R. Williams and R. D. Lacewell, Simulating corn yield response to irrigation timings: validation of the Epic model, J. Prod. Agric. 5 (1992), pp. 237-242.

Claassen and Shaw, $1970 \rightarrow$ M. M. Claassen and R. H. Shaw, Water deficit effects on corn. II. Grain components, Agron. J. 62 (1970), pp. 652-655.

Dale and Daniels, $1995 \rightarrow$ R. F. Dale and J. A. Daniels, A weather-soil variable for estimating soil moisture stress and corn yield probabilities, Agron. J. 87 (1995), pp. 11151121.

Denmead and Shaw, 1960 O. T. Denmead and R. H. Shaw, The effects of soil moisture stress at different stages of growth on the development and yield of corn, Agron. J. 52 (1960), pp. 272-274.

Downey, 1971 L. A. Downey, Effect of gypsum and drought stress on maize (Zea mays L.). I. Growth, light absorption and yield, Agron. J. 63 (1971), pp. 569-572.

Doorenbos and Kassam, 1979 Doorenbos, J., Kassam, A. H., 1979. Yield response to water. In: Johl, S. S. (Ed.), Irrigation and Agricultural Development: Based on an International Expert Consultation, Baghdad Iraq. Pergamon Press, New York, NY.

Doorenbos et al., 1979 Doorenbos, J., Kassam, A. H., Bentvelsen, C., Uittenbogaard, G., 1979. Yield response to water. FAO Irrigation and Drainage Paper No. 33, FAO, Rome, Italy. 193 pp.

Gavloski et al., 1992 J. E. Gavloski, G. H. Whitfield and C. R. Ellis, Effect of restricted watering on sap flow and growth in corn (Zea mays L.), Can. J. Plant Sci. 72 (1992), pp. 361-368.

Gilley et al., 1980 J. R. Gilley, D. G. Watts and C. Y. Sullivan, Management of Irrigation Agriculture with a Limited Water and Energy Supply, Institute of Agriculture and Natural Resources, University of Nebraska-Lincoln (1980) pp. 168.

Hanks, 1974 R. J. Hanks, Model for predicting plant yield as influenced by water use, Agron. J. 66 (1974), pp. 660-664.

Hanks et al., 1976 R. J. Hanks, J. Keller, V. P. Rasmussen and G. D. Wilson, Line source sprinkler for continuous variable irrigation-crop production studies, Soil Sci. Soc. Am. J. 40 (1976), pp. 426-429. 
Hergert et al., $1993 \rightarrow$ G. W. Hergert, N. L. Klocke, J. L. Petersen, P. T. Nordquist, R. T. Clark and G. A. Wicks, Cropping systems for stretching limited irrigation supplies, J. Prod. Agric. 6 (1993), pp. 520-528.

Howell, 2000 T. A. Howell, Irrigation's role in enhancing water use efficiency, Proceedings of the Fourth Decennial Symposium ASAE, Phoenix, Arizona, November 14-16 (2000), pp. 66-80.

Jama and Ottman, 1993 A. O. Jama and M. J. Ottman, Timing of the first irrigation in corn and water stress conditioning, Agron. J. 85 (1993), pp. 1159-1164.

Jensen, 1968 M. E. Jensen, Water consumption by agricultural plants. In: T. T. Kozlowski, Editor, Water Deficits and Plant Growth, Academic Press, New York (1968), pp. 1-22.

Jurgens et al., $1978 \rightarrow$ S. K. Jurgens, R. R. Johnson and J. S. Boyer, Dry matter production and translocation in maize subjected to drought during grain fill, Agron. J. 70 (1978), pp. 678-682.

Kijne et al., 2003 Kijne, J. W., Tuong, T. P., Bennett, J., Bouman, B., Oweis, T., 2003. Ensuring food security via improvement in crop water productivity. In: Challenge Program on Water and Food: Background Papers to the full proposal. The Challenge Program on Water and Food Consortium, Sri Lanka.

Klocke et al., $1999>$ N. L. Klocke, D. G. Watts, J. P. Schneekloth, D. R. Davison, R. W. Todd and A. M. Parkhurst, Nitrate leaching in irrigated corn and soybean in a semi-arid climate, Trans. ASAE 42 (1999), pp. 1621-1630.

Klocke et al., $2004-$ N. L. Klocke, J. P. Schneekloth, S. Melvin, R. T. Clark and J. O. Payero, Field scale limited irrigation scenarios for water policy strategies, Appl. Eng. Agric. 20 (2004), pp. 623-631.

Lingle and Franti, 1998 Lingle, G. R., Franti, T. G., 1998. What is the "Cooperative Agreement" for Endangered Species Habitat Along the Central Platte Rive? NebFact NF98-375. University of Nebraska-Lincoln Cooperative Extension Publication, available at: http://ianrpubs. unl. edu/wildlife/nf375. htm (5 pp.)

Lorens et al., 1987 G. F. Lorens, J. M. Bennett and L. B. Loggale, Differences in drought resistance between two corn hybrids. II. Component analysis and growth rates, Agron. J. 79 (1987), pp. 808-813.

McGuire and Fischer, 1999 McGuire, V. L., Fischer, B. C., 1999. Water-level Changes, 1980-1997 and Saturated Thickness, 1996-97, in the High Plains Aquifer. Fact Sheet 124-99. U. S. Geological Survey, Lincoln.

McGuire, 2004 McGuire, V. L., 2004. Water-level Changes in the High Plains Aquifer, predevelopment to 2002, 19802002, and 2001-2002. Fact Sheet 2004-3026. U. S. Geological Survey, Lincoln.

Meyer et al., 1993a $>$ S. J. Meyer, K. G. Hubbard and D. A. Wilhite, A crop-specific drought index for corn. I. Model development and validation, Agron. J. 85 (1993), pp. 388395.
Meyer et al., 1993b $>$ S. J. Meyer, K. G. Hubbard and D. A. Wilhite, A crop-specific drought index for corn. II. Application in drought monitoring and assessment, Agron. J. 85 (1993), pp. 396-399.

Nairizi and Rydzewski, 1977 S. Nairizi and J. R. Rydzewski, Effects of dated soil moisture stress on crop yields, Exp. Agric. 13 (1977), pp. 51-59.

NeSmith and Ritchie, 1992 D. S. NeSmith and J. T. Ritchie, Short- and long-term responses of corn to pre-anthesis soil water deficit, Agron. J. 84 (1992), pp. 107-113.

Newell and Wilhelm, $1987 \rightarrow$ R. L. Newell and W. W. Wilhelm, Conservation tillage and irrigation effects on corn root development, Agron. J. 79 (1987), pp. 160-165.

Norwood, $2000>$ C. A. Norwood, Water use and yield of limited-irrigated and dryland corn, Soil Sci. Soc. Am. J. 64 (2000), pp. 365-370.

Robinson and Hubbard, $1990 \rightarrow$ J. M. Robinson and K. G. Hubbard, Soil water assessment model for several crops in the High Plains, Agron. J. 82 (1990), pp. 1141-1148.

Robins and Domingo, 1953 J. S. Robins and C. E. Domingo, Some effects of severe soil moisture deficit at specific growth stages in corn, Agron. J. 45 (1953), pp. 618-621.

Schneekloth et al., 1991 J. P. Schneekloth, N. L. Klocke, G. W. Hergert, D. L. Martin and R. T. Clark, Crop rotations with full and limited irrigation and dryland management, Trans. ASAE 34 (1991), pp. 2372-2380.

Schneekloth et al., 1995 J. P. Schneekloth, R. T. Clark, S. A. Coady, N. L. Klocke and G. W. Hergert, Influence of wheat-feed grain programs on riskiness of crop rotations under alternate irrigation levels, J. Prod. Agric. 8 (1995), pp. $415-423$.

Stone, 2003 L. R. Stone, Crop water use requirements and water use efficiencies, Proceedings of the 15th annual Central Plains Irrigation Conference and Exposition Colby, Kansas, February 4-5 (2003), pp. 127-133.

Swan et al., 1990 J. B. Swan, J. A. Staricka, M. J. Shaffer, W. H. Paulson and A. E. Peterson, Corn yield response to water stress, heat units, and management: model development and calibration, Soil Sci. Soc. Am. J. 54 (1990), pp. 209-216.

Traore et al., 2000 S. B. Traore, R. E. Carlson, C. D. Pilcher and M. E. Rice, Bt and Non-Bt maize growth and development as affected by temperature and drought stress, Agron. J. 92 (2000), pp. 1027-1035.

Wright, $1982 \longrightarrow \mathrm{J}$. L. Wright, New evapotranspiration crop coefficients, J. Irrig. Drain. Div. 108 (1982), pp. 57-74.

Yang et al., 2004 H. S. Yang, A. Dobermann, J. L. Lindquist, D. T. Walters, T. J. Arkebauer and K. G. Cassman, Hybridmaize - a maize simulation model that combines two crop modeling approaches, Field Crops. Res. 87 (2004), pp. 131154.

Zwart and Bastiaanssen, $2004 \longrightarrow$ S. J. Zwart and W. G. M. Bastiaanssen, Review of measured crop water productivity values for irrigated wheat, rice, cotton and maize, Agric. Water Manag. 69 (2004), pp. 115-133. 